\title{
JNK/SAPK activity contributes to TRAIL-induced apoptosis
}

\author{
Ingrid Herr', Dagmar Wilhelm ${ }^{2,3}$, Eric Meyer ${ }^{1,4}$, \\ Irmela Jeremias ${ }^{1}$, Peter Angel ${ }^{2}$ and \\ Klaus-Michael Debatin ${ }^{\star, 1,4}$ \\ 1 Division of Molecular Oncology, Deutsches Krebsforschungszentrum, \\ Heidelberg, Germany \\ 2 Division of Signal Transduction, Deutsches Krebsforschungszentrum, \\ Heidelberg, Germany \\ ${ }^{3}$ Forschungszentrum Karlsruhe, Institute of Genetics, Karlsruhe, Germany \\ ${ }^{4}$ Universitäts Kinderklinik, Ulm, Germany \\ * corresponding author: Prof. Dr. Klaus-Michael Debatin, Universitäts \\ Kinderklinik, Prittwitzstr. 43, D-89075 Ulm, Germany. tel: +49-731-502 7701; \\ fax: +49-731-502 6681
}

Received 28.5.98; revised 26.8.98; accepted 13.10 .98 Edited by S.J. Martin

\begin{abstract}
We report here that JNK/SAPKs are activated by TRAIL in parallel to induction of apoptosis in human $T$ and $B$ cell lines. Death signaling as well as JNK/SAPK activation by TRAIL in these cells is FADD- and caspase-dependent since dominantnegative FADD or the caspase inhibitor ZVAD prevented both, apoptosis and JNK/SAPK activity. JNK/SAPK activity in response to triggering of $\mathrm{CD} 95$ by an agonistic antibody $(\alpha \mathrm{APO}-1)$ was also diminished by dominant-negative FADD or zVAD. Correspondingly, a cell line resistant to $\alpha A P O-1$ induced death exhibited crossresistance to TRAIL-induced apoptosis and did not upregulate JNK/SAPK activity in response to TRAIL or $\alpha$ APO-1. Inhibition of JNK/SAPK activity, by stably transfecting cells with a dominant-negative JNKKMKK4 construct, reduced apoptosis in response to TRAIL or $\alpha$ APO-1. Therefore, activation of JNK/SAPKs by TRAIL or $\alpha A P O-1$ occurs downstream of FADD and caspases and contributes to apoptosis in human lymphoid cell lines.
\end{abstract}

Keywords: apoptosis; TRAIL (APO2-L); CD95-L (APO1-L/Fas-L); JNKK-MKK4

Abbreviations: JNK, c-Jun N-terminal kinase; SAPK, stressactivated protein kinase; JNKK-MKK4, c-Jun N-terminal kinase, MAP kinase kinase; DILs, Death-inducing ligands; $\alpha$ APO-1, agonistic CD95 receptor antibody; TRAIL-R1, TRAIL Receptor 1; TRAIL-R2, TRAIL Receptor 2; TNF, Tumor Necrosis Factor; TNFR1, Tumor Necrosis Factor Receptor 1; SD, Standard Deviations

\section{Introduction}

TRAIL (also known as APO-2 ligand) is a member of the tumor necrosis factor (TNF) family of death inducing ligands
(DILs) and leads to apoptosis in a wide variety of cells. ${ }^{1,2}$ The effects of TRAIL are mediated by five distinct cell surface receptors and two of them possess an intact intracellular 'death domain'. ${ }^{-7}$ Among members of the TNF receptor superfamily this intracellular 'death domain' is significantly conserved and required to transduce the apoptosis-inducing signal through interaction with the 'death domains' of adapter proteins. ${ }^{4,5,8-10}$ FADD is a major adapter molecule which binds either directly or indirectly to the death domains of CD95 receptor (CD95), TNF receptor 1 (TNF-R1) or TRAIL receptor 1 (TRAIL-R1) and TRAIL receptor 2 (TRAIL-R2) to transduce the apoptotic signal by activation of caspase 8 (FLICE) followed by sequential activation of other caspases. , $8,9,11-14^{\text {The }}$ emerging model from these molecular studies is that death receptors via adapter proteins like FADD directly engage and activate apoptotic ICE family proteases. However, this model fails to explain how diverse physiologic signals like sphingosine-1-phosphate, ${ }^{15}$ activation of protein kinase $\mathrm{C}$ by phorbol esters ${ }^{16}$ or $\mathrm{Bcl}-2^{17,18}$ may modulate death receptor-mediated apoptosis.

Cross-linking of CD95 and TNF-R1 can also activate the Jun N-terminal kinase/stress-activated protein kinase (JNK/ SAPK) pathway. ${ }^{19-24}$ The significance of JNK/SAPK activation has been unclear. One hypothesis is that activation of the JNK/SAPK pathway contributes to CD95and TNF-mediated apoptosis ${ }^{22,25,26}$ whereas others ${ }^{23,24}$ suggested that JNK/SAPK activation is not required for TNF-R1-induced apoptosis. Recently, a novel signaling protein, DAXX was identified that binds specifically to the CD95 death domain. Overexpression of DAXX enhanced CD95-mediated apoptosis by activation of the JNK/SAPK pathway in a FADD independent manner. ${ }^{26}$ Correspondingly, activation of JNK/SAPKs by TNF-R1 is described to be mediated through a TRAF2 pathway which also acts independently of FADD. ${ }^{23,24}$

Signaling events downstream of TRAIL receptors are largely unknown. We found an involvement of JNK/SAPKs in apoptosis signaling downstream of FADD and caspases following ligation of TRAIL and $\alpha$ APO-1 in human lymphoid cell lines.

\section{Results}

TRAIL induces JNK/SAPK activity downstream of caspases

To examine whether JNK/SAPKs are activated during TRAIL-induced apoptosis we analyzed JNK/SAPK activity in human $T$ (JURKAT) and $B$ (BJAB) cell lines following treatment with recombinant TRAIL protein. Crosslinking of TRAIL leads to a rapid induction of JNK/SAPKs within $2 \mathrm{~h}$ which parallels the onset of apoptosis (Figure 1A,B). TRAIL- 
control supernatant from Pichia pastoris transfected with empty vector induced neither significant JNK/SAPK activity nor apoptosis. Next we measured TRAIL-induced JNK/ SAPK activity in the presence of ZVAD, an inhibitory peptide substrate for caspases which also blocks the receptor proximal caspase FLICE. ${ }^{27}$ Pre-incubation of JURKAT cells with zVAD completely prevented TRAIL-induced JNK/SAPK activity and cell death. In contrast, $\alpha$ APO-1-mediated activity of JNK/SAPKs was not totally prevented by zVAD (Figure 1D). This might be due to a cross-talk between the FADDand DAXX-dependent signaling pathways initiated by triggering of CD95. ${ }^{26}$ TRAIL-induced JNK/SAPK activity and apoptosis was also not detectable in JURKAT-derived JAPO cells. This cell line exhibits cross-resistance towards TRAIL and $\alpha$ APO-1-mediated apoptosis and does neither cleave caspases nor activate JNK/SAPKs although CD95 receptor is expressed (Figure $1 \mathrm{~A}$ and $\mathrm{C}$ and data not shown). This suggests that TRAIL induces JNK/SAPK activity downstream of FLICE/caspases in lymphoid cell lines similar as shown for CD95 signaling (Figure 1D). ${ }^{19}$ Therefore, a common element of the CD95 and TRAIL pathway might be defective in JAPO cells which is necessary for JNK/SAPK activation.

\section{TRAIL-induced apoptosis and JNK/SAPK activity depends on intact FADD signaling}

To further dissect the TRAIL-induced pathway leading to JNK/ SAPK activation we determined the effect of FADD signaling located upstream of FLICE/caspases and used a B cell line in which FADD signaling was blocked by stable transfection of a FADD dominant-negative construct (BJAB-FADD-DN cells). In BJAB-FADD-DN cells apoptosis and activation of JNK/ SAPKs induced by treatment with TRAIL was totally inhibited compared to the vector control line (Figure 2A and B). The same result was obtained after ligation of CD95 in mutant and control BJAB cells (Figure $2 \mathrm{C}$ and $\mathrm{D}$ ). Thus, death signaling downstream of TRAIL and CD95 receptors may use common elements in the following sequence: death-receptors $\rightarrow$ FADD $\rightarrow$ caspases $\rightarrow$ JNK/SAPKs.

\section{TRAIL-induced apoptosis is attenuated in cells stably transfected with a JNKK-MKK4 dominant-negative construct}

To examine more specifically whether enhanced JNK/SAPK activity might contribute to TRAIL-induced apoptosis we

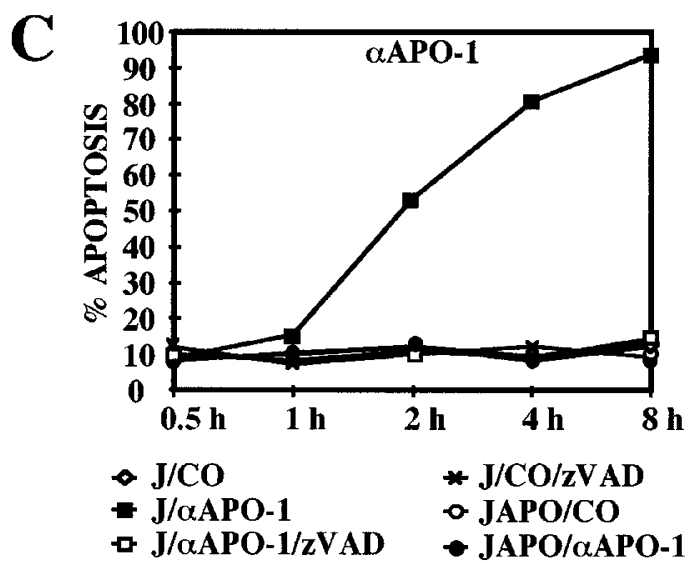

D

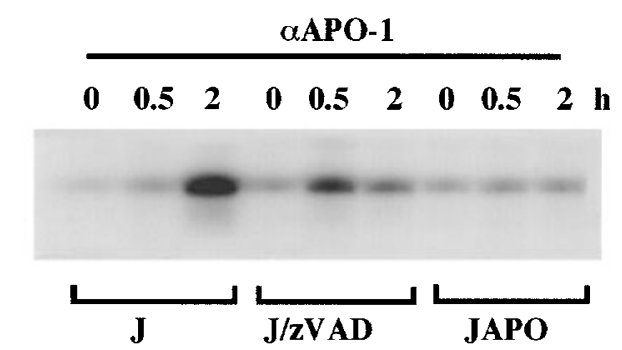

Figure 1 TRAIL-induced JNK/SAPK activity occurs downstream of caspases. (A) JURKAT (J) or $\alpha$ APO-1 resistant JURKAT cells JAPO were incubated with $100 \mathrm{ng} / \mathrm{ml}$ recombinant TRAIL protein (J/TR; JAPO/TR) or with control supernatant from Pichia pastoris transfected with empty vector (J/V; JAPO/V). Likewise, JURKAT cells were pre-incubated with $50 \mu \mathrm{M}$ zVAD and subsequently treated with TRAIL or control supernatant (J/TR/zVAD; J/V/zVAD). $0.5,1,2,4$ or $8 \mathrm{~h}$ later early apoptotic changes were measured by annexin staining using flow cytometry. (B) Cells were treated in a similar way as described in A and at the time points indicated nuclei-free supernatant was normalized for protein content and immunoprecipitated with anti-JNK/SAPK antibody-conjugated sepharose beads. GSTcJun-1-166 fusion protein was added to the immuno complexes and incubated in kinase buffer in the presence of [ $\left.\gamma-{ }^{32} \mathrm{P}\right] \mathrm{ATP}$. The phosphorylated fusion protein was resolved by $10 \%$ SDS - PAGE and visualized by autoradiography. (C and D) Cells were treated and analyzed as described in (A and $\mathbf{B})$ except that cells were treated with $\alpha$ APO-1 agonistic antibody $(\alpha \mathrm{APO}-1,2 \mu \mathrm{g} / \mathrm{ml})$ instead of TRAIL. The results depicted are the mean of three separate experiments \pm S.D. 
inhibited JNK/SAPK activity by transfecting JURKAT cells with a dominant-negative JNKK-MKK4 construct which partially inhibits JNK/SAPK activity. ${ }^{28}$ JNKK-MKK4 has been shown to be a direct activator for JNK/SAPKs. ${ }^{29}$ Cotransfection with the gene for the GFP marker protein enabled separate forward side scatter FACScan analysis of transfected cells. However, using this treatment, cell death induced by stimulation with TRAIL or $\alpha$ APO- 1 for 8 and $24 \mathrm{~h}$, respectively, was not significantly influenced compared to empty vector transfected control cells (Figure 3A). The same result was found using CEM leukemic $T$ cells. However, detection of cell death by gating on GFP-cotransfected cells is less sensitive than measuring apoptosis. Furthermore, an enhancement of TRAIL and/or CD95-induced apoptosis could not be recorded in transfectants which died already. Therefore we selected stably transfected cells by continuous culture in G418. This treatment strongly diminished activity of JNKSAPKs compared to empty vector transfected cells as examined by a kinase assay (Figure 3B). In control experiments we detected expression of $\alpha$-Tubulin and the amount of phosphorylated ERK protein by Western blot. Whereas $\alpha$-Tubulin was found to be equal expressed in both cell lines phosphorylation of ERKs in cells with a repressed JNK/SAPK activity was induced. This is in line with the recent finding that a balance between JNK/SAPK and ERK affects the apoptotic outcome since activation of the JNK/SAPK pathway in combination with a repressed growth factor activated ERK-cascade was required for apoptosis. ${ }^{30}$ Correspondingly, apoptosis induced by stimulation with TRAIL or $\alpha$ APO-1 for 4 and $8 \mathrm{~h}$, respectively, was strongly diminished in cells with a repressed JNK/SAPK activity compared to empty vector transfected control cells as detected by annexin-staining and flow cytometry (Figure $3 \mathrm{C})$. The same result was found in HeLa cells stably transfected with JNKK-MKK4 dominant-negative or empty vector. Therefore, activation of JNK/SAPKs contributes to apoptosis signaling downstream of death receptors.

\section{Discussion}

In the present study we demonstrate that JNK/SAPKs are activated in response to treatment of leukemic T cell lines with TRAIL in a similar kinetic as found for cross-linking of CD95. Both, TRAIL- and CD95-induced JNK/SAPK activity was inhibited by preventing signaling of FADD or caspases. Furthermore, inhibition of JNK/SAPKs in cells stably transfected with dominant-negative JNKK-MKK4 diminished TRAIL or $\alpha$ APO-1-mediated apoptosis. Therefore, activation of JNK/SAPKs may contribute to apoptosis signaling downstream of death receptors. However, death signaling in lymphoid cell lines seems to differ from the pathway initiated in HeLa, 293 or MCF7 cells since in these systems a dichotomy upstream of FADD leading to JNK/SAPK activity was described. Thus, crosslinking of CD95 or TNF-R1 in
A

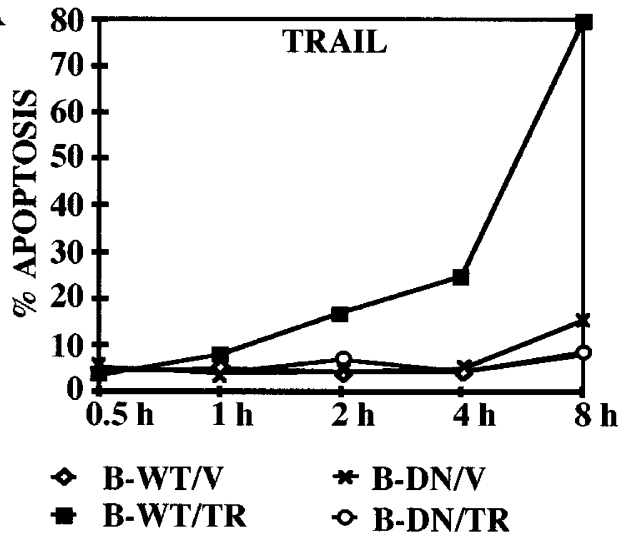

B

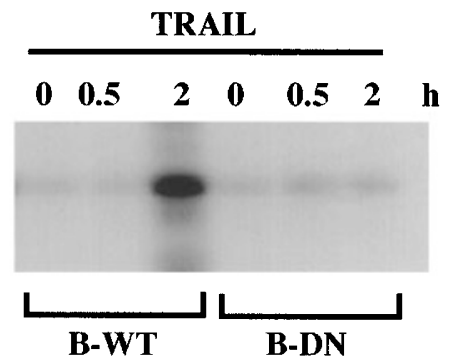

C

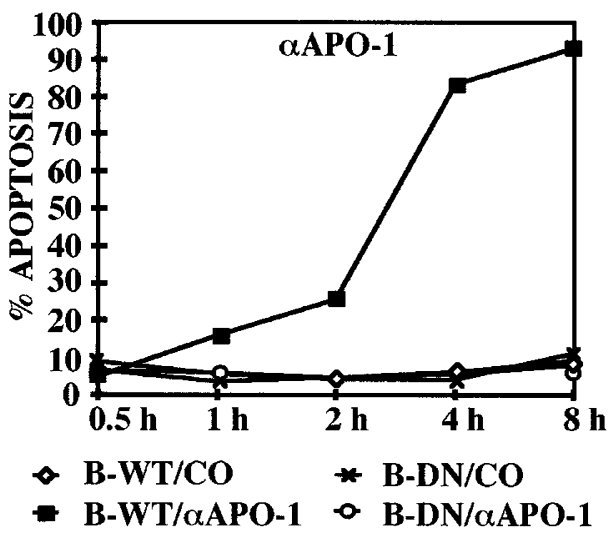

D

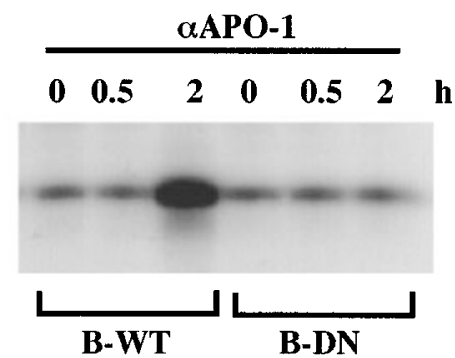

Figure 2 TRAIL-induced apoptosis and JNK/SAPK activity depends on intact FADD signaling in human B cells. Human B lymphoma BJAB cells stably transfected with pcDNA3 carrying the cDNA for inactive FADD-WT (B-WT) or a pcDNA3-FADD-DN construct (B-DN) were treated with TRAIL or $\alpha$ APO-1 and analyzed as described in Figure 1 
A

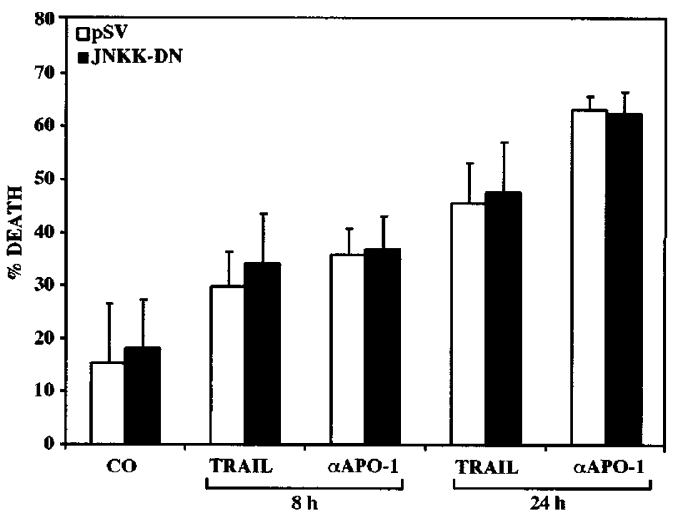

B

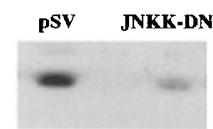

GST-eJUN

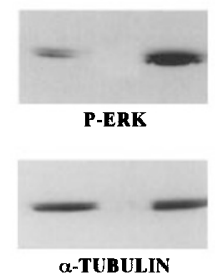

$\mathbf{C}$

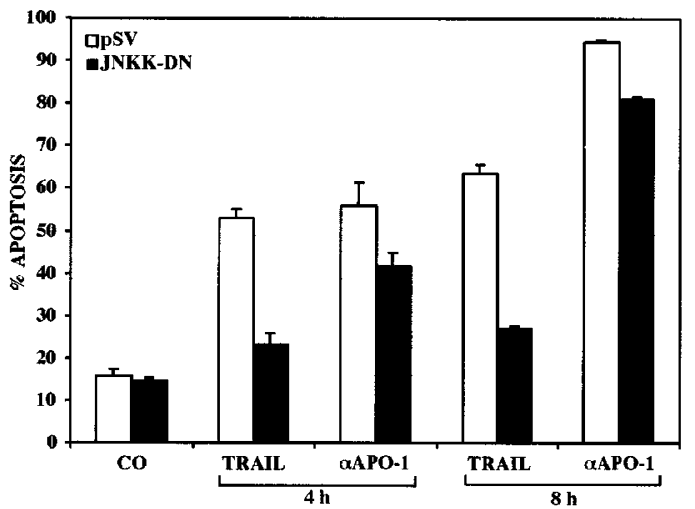

Figure 3 TRAIL-induced apoptosis in transiently and stably transfected cells harboring dominant-negative JNKK-MKK4. (A) JURKAT cells were transfected with empty vector (pSV, white bars) or vector containing the cDNA for JNKK-MKK4 dominant-negative (JNKK-DN, black bars) and cotransfected with pEGFP as described in Materials and Methods. Seventy-two hours after transfection cells were stimulated with recombinant TRAIL $\mathrm{protein}(100 \mathrm{ng} / \mathrm{ml})$ or $\alpha \mathrm{APO}-1$ ( $1 \mu \mathrm{g} / \mathrm{ml}$ ). Eight or $24 \mathrm{~h}$ later cell death was measured by forward side scatter analysis by gating at GFP-positive cells using a FACScan cytometer. The percentage of GFPpositive cells $72 \mathrm{~h}$ after transfection was $26 \%$ (pSV) and $23 \%$ (JNKK-DN). (B) JNK/SAPK activity of untreated JURKAT cells stably transfected with empty vector (pSV) or vector containing the cDNA for JNKK-MKK4-dominant-negative (JNKK-DN) was examined by kinase assay as described in Figure 1B and D and Materials and Methods. In addition, the amount of phosphorylated ERK or the expression of $\alpha$-Tubulin proteins was examined by Western blot using extracts from the same cells. (C) JURKAT cells stably transfected with empty vector (pSV, white bars) or vector containing the cDNA for JNKK-MKK4 dominant-negative (JNKK-DN, black bars) were stimulated with recombinant TRAIL protein $(100 \mathrm{ng} / \mathrm{ml})$ or $\alpha$ APO-1 $(1 \mu \mathrm{g} / \mathrm{ml})$. After 4 or $8 \mathrm{~h}$ apoptosis was analyzed by annexin-staining and flow cytometry. The results depicted are the mean of three separate experiments performed in duplicates \pm S.D

HeLa, 293 or MCF7 cells seems to engage predominantly the death domain adapter proteins DAXX and TRAF2, respectively which define a pathway distinct from FADD/FLICE/ caspases to activate JNK/SAPKs. ${ }^{23,24,26,31}$ DAXX-signaling might also contribute to CD95-mediated JNK/SAPK activity in lymphoid cells since we observed that inhibition of caspases prevented not in all cases $\alpha$ APO-1-mediated activity of these kinases. In contrast, TRAIL-induced JNK/SAPK activity was totally blocked by zVAD, dominant-negative FADD and in $\alpha A P O-1$-resistant JAPO cells suggesting that FADD is a critical element for activation of JNK/SAPKs by TRAIL. However, the contribution of the individual receptors for TRAIL in induction of JNK/SAPK activity remains to be further highlighted.

The precise role of JNK/SAPK activation following direct triggering of death receptors is unclear. Our data correspond to the recent findings that JNK/SAPK activation contributes to CD95-mediated apoptosis since counteracting activation of JNK/SAPKs by sphingosine-1-phosphate inhibits CD95-induced cell death in some cells ${ }^{15}$ and activation of JNK/SAPKs by overexpression of DAXX induces apoptosis. ${ }^{26}$ Furthermore, activity of ASK-1, an apoptosis signal-regulating kinase of the JNK/SAPK pathway which can be activated by DAXX is both sufficient to mediate apoptosis and required for TNF- $\alpha$-induced cell death. $^{32,33}$

Paradoxically, JNK/SAPK activation in response to various stimuli was also demonstrated to be dispensable

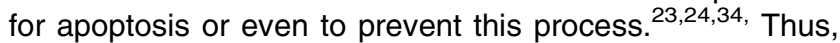
the JNK/SAPK pathway might directly or indirectly counteract the expression of survival factors, such as $\mathrm{NF}-\kappa \mathrm{B}^{24}$ or
Bcl-2. ${ }^{35}$ Correspondingly, activation of the JNK/SAPK pathway in combination with a repressed growth factor activated ERK-cascade has been shown to be required for apoptosis and a balance between JNK/SAPK and ERK has been found to be critical in affecting the apoptotic outcome. $^{30}$ In addition, JNK/SAPK activity may also occur independently of death receptor triggering as described in response to cellular stress. ${ }^{36}$ In contrast to direct triggering of death receptors inhibition of caspases by zVAD did not prevent but even superinduced activity of JNK/SAPKs in response to cellular stress in lymphoid cells. ${ }^{37}$

Thus, the co-operation of multiple signaling pathways as well as cell type-specific variations allows fine-tuned, targeted regulation and creates multiple checkpoints for the modulation of death signals.

\section{Materials and Methods}

\section{Reagents and cell lines}

zVAD (Enzyme Systems Products, Dublin, USA) stock was dissolved in dimethylsulfoxide and stored in aliquots at $-20^{\circ} \mathrm{C}$. Final concentrations of the solvent in medium were $0.1 \%$. Anti-CD95agonistic antibody ( $\alpha$ APO -1$)$ and recombinant TRAIL were prepared as previously described. ${ }^{14,38}$ Stock solutions were dissolved in PBS.

The following human cell lines were used: Apoptosis-sensitive JURKAT (acute human T cell leukemia) cells which rapidly die in response to treatment with $\alpha$ APO-1. An $\alpha$ APO-1-resistant subclone (JAPO) has been selected by continuous culture of the parental JURKAT cells in increasing doses of $\alpha$ APO- 1 during a period of 1 year 
(starting with doses of $10 \mathrm{ng}$ and ending at $10 \mu \mathrm{g} / \mathrm{ml}$ ). BJAB is a human $B$ lymphoma cell line stably transfected with pcDNA3 vector carrying the cDNA for inactive FADD-WT (BJAB-WT) or a pcDNA3FADD-DN construct (BJAB-FADD-DN) as described. ${ }^{39}$ All cell lines were grown in RPMI-1640 medium supplemented with $10 \%$ FCS (Biochrom, Hamburg, Germany), $100 \mathrm{U} / \mathrm{ml}$ penicillin, $100 \mu \mathrm{g} / \mathrm{ml}$ streptomycin, $25 \mathrm{mM}$ HEPES and $2 \mathrm{mM}$ L-glutamine (all from Boehringer Ingelheim, Germany). For selection of stably transfected JURKAT cells $25 \mu \mathrm{g}$ of either pSV empty vector or a JNKK-MKK4 dominant-negative expression construct were transfected by electroporation $(975 \mu \mathrm{F}, 220 \mathrm{~V})$. Transfected cells were resuspended in $10 \mathrm{ml}$ fresh medium and living cells were selected by continuous culture in G418 (Calbiochem, California, USA).

\section{Measurement of apoptosis}

Early apoptotic changes were identified by staining of cells with fluoresceinthiocyanate (FITC)-conjugated annexin V (Bender Med Systems, Vienna, Austria) and analyzed by flow cytometry (FACScan, Becton Dickinson, Heidelberg, Germany) as described. ${ }^{36}$

\section{JNK/SAPK assay}

JNK/SAPKs were immunoprecipitated with polyclonal antibodies raised against JNK1 (C-17, Santa Cruz, USA) and JNK2 (FL-18, Santa Cruz, USA) and activity was detected using GST-Jun 1/166 as substrate as described. ${ }^{28,36}$

\section{Western blot}

Expression of $\alpha$-Tubulin and the amount of phosphorylated ERK proteins was detected by Western blotting as described. ${ }^{36} \alpha$-Tubulin was stained with a mouse monoclonal antibody obtained from Calbiochem (California, USA). Phosphorylated ERK was detected using a specific mouse monoclonal antibody (Santa Cruz, California, USA). Bound antibodies were detected by anti-mouse/horseradish peroxidase conjugates (Santa Cruz, California, USA). Enhanced chemiluminescence system (Amersham, Braunschweig, Germany) was used for detection.

\section{Transient transfections}

$1 \times 10^{8}$ JURKAT cells were pelleted, resuspended in $200 \mu \mathrm{l}$ PBS and transfected with $25 \mu \mathrm{g}$ expression construct and $5 \mu \mathrm{g}$ GFP construct by electroporation ( $975 \mu \mathrm{F}, 220 \mathrm{~V})$. After transfection the cells were separated by Ficoll-gradient centrifugation and resuspended in fresh medium at $5 \times 10^{5} / \mathrm{ml}$. Twenty-four hours later living cells were Ficollseparated again and resuspended in fresh medium at $5 \times 10^{5} / \mathrm{ml}$. Twelve hours or $24 \mathrm{~h}$ later cells were stimulated.

\section{Acknowledgements}

We thank Dr. V. Dixit for kindly providing BJAB-FADD-DN cells and A Frezza and G. Hölzl-Wenig for excellent technical assistance. This work was supported by 'Deutsche Leukaemic forschungshilfe'

\section{References}

1. Wiley SR, Schooley K, Smolak PJ, Din WS, Huang CP, Nicholl JK, Sutherland GR, Davis T, Rauch C, Smith CA and Goodwin RG (1995) Identification and characterization of a new member of the TNF family that induces apoptosis. Immunity 3: 673-682
2. Pitti RM, Marsters SA, Ruppert S, Donahue CJ, Moore A and Ashkenazi A (1996) Induction of apoptosis by Apo-2 ligand, a new member of the tumor necrosis factor cytokine family. J. Biol. Chem. 271: 12687-12690

3. Pan G, O'Rourke K, Chinnaiyan AM, Gentz R, Ebner R, Ni J and Dixit VM (1997) The receptor for the cytotoxic ligand TRAIL. Science 276: 111-113

4. Sheridan JP, Marsters SA, Pitti RM, Gurney A, Skubatch M, Baldwin D, Ramakrishnan L, Gray CL, Baker K, Wood WI, Godard AD, Godowski P and Ashkenazi A (1997) Control of TRAIL-induced apoptosis by a family of signaling and decoy receptors. Science 277: 818-820

5. Walczak H, Degli-Esposti MA, Johnson RS, Snolak PJ, Waugh JY, Boiani N, Timour MS, Gerhart MJ, Schooley KA, Smith CA, Goodwin RG and Rauch CT (1997) TRAIL-R2: a novel apoptosis-mediating receptor for TRAIL. EMBO J. 16: $5386-5397$

6. Degli-Esposti MA, Dougall WC, Smolak PJ, Waugh JY, Smith CA and Goodwin RG (1998) The novel receptor TRAIL-R4 induces NF- $\kappa$ B and protects against TRAIL-mediated apoptosis, yet retains an incomplete death domain. Immunity 7 : 813-820

7. Emery JG, McDonnell P, Brigham Burke M, Deen KC, Lyn S, Silverman C, Dul E, Appelbaum ER, Eichman C, DiPrinzio R, Dodds RA, James IE, Rosenberg M, Lee JC and Young PR (1998) Osteoprotegerin is a receptor for the cytotoxic ligand TRAIL. J. Biol. Chem. 273: 14363-14367

8. Schneider P, Thome M, Burns K, Bodmer J-L, Hofmann K, Kataoka T, Holler N and Tschopp J (1998) TRAIL receptors 1 (DR4) and 2 (DR5) signal FADDdependent apoptosis and activate NF- $\kappa$ B. Immunity $7: 831-836$

9. Chaudhary PM, Eby M, Jasmin A, Bookwalter A, Murray J and Hood L (1998) Death receptor 5 , a new member of the TNFR family, and DR4 induce FADDdependent apoptosis and activate the NF- $\kappa$ B pathway. Immunity $7: 821-830$

10. Nagata S (1997) Apoptosis by death factor. Cell 88: 355-365

11. Muzio M, Chinnaiyan AM, Kischkel FC, O'Rourke K, Shevchenko A, Ni J, Scaffidi C, Bretz JD, Zhang M, Gentz R, Mann M, Krammer P, Peter ME and Dixit VM (1996) FLICE, a novel FADD-homologous ICE/CED-3-like protease, is recruited to the CD95/Fas/APO-1 death-inducing signaling complex. Cell 85: 817-827

12. Boldin MP, Goncharov TM, Goltsev YV and Wallach D (1996) Involvement of $\mathrm{MACH}$, a novel MORT/FADD-interacting protease, in Fas/APO-1- and TNFreceptor-induced cell death. Cell 85: 803-815

13. Mariani SM, Matiba B, Armandola EA and Krammer PH (1997) Interleukin $1 \beta$ converting enzyme related proteases/caspases are involved in TRAIL-induced apoptosis of myeloma and leukemia cells. J. Cell. Biol. 137: 221-229

14. Jeremias I, Herr I, Bochler T and Debatin K-M (1998) TRAIL/APO-2-ligandinduced apoptosis in human T cells. Eur. J. Immunol. 28: 143-152

15. Cuvillier O, Pirianov G, KleuserB, VanekPG, Coso OA, Gutkind JS and Spiegel S (1996) Suppression of ceramide-mediated programmed cell death by sphingosine-1-phosphate. Nature 381: 800-803

16. Tepper CF, Jayadev S, Liu B, Bielawska A, Wolff R, Yonehara S, Hannun YA and Seldin MF (1995) Role for ceramide as an endogenous mediator of Fas-induced cytotoxicity. Proc. Natl. Acad. Sci. USA 92: 8443-8447

17. Fraser A and Evan G (1996) A license to kill. Cell 89: 1067-1076

18. Susin SA, Zamzami N, Castedo M, Daugas E, Wang H-G, Geley S, Fassy F, Reed JC and Kroemer G (1997) The central executioner of apoptosis: multiple connections between protease activation and mitochondria in Fas/APO-1/ CD95- and ceramide-induced apoptosis. J. Exp. Med. 186: 25-37

19. Cahill MA, Peter ME, Kischkel FC, Chinnaiyan AM, Dixit VM, Krammer PH and Nordheim A (1996) CD95 (APO-1/Fas) induces activation of SAP kinases downstream of ICE-like proteases. Oncogene 13: 2087-2096

20. Wilson JW, Fortner KA, Lynch DH, Mattingly RR, Macara IG, Posada JA and Budd RC (1996) JNK, but not MAPK, activation is associated with Fas-mediated apoptosis in human T cells. Eur. J. Immunol. 26: 989-994

21. Latinis KM, Carr LL, Peterson EJ, Norian LA, Eliason SL and Koretzky GA (1997) Regulation of CD95 (Fas) ligand expression by TCR-mediated signaling events. J. Immunol. 158: 4602-4611

22. Verheij M, Bose R, Hua Lin X, Yao B, Jarvis WD, Grant S, Birrer MJ, Szabo E, Zon LI, Kyriakis JM, Haimovitz-Friedman A, Fuks Z and Kolesnick RN (1996) Requirement for ceramide initiated JNK/SAPK signalling in stress-induced apoptosis. Nature 380: 75-79

23. Liu Z-G, Hsu H, Goeddel DV and Karin M (1996) Dissection of TNF receptor 1 effector functions: JNK activation is not linked to apoptosis while NF- $\kappa$ B activation prevents cell death. Cell 87: 565-576

24. Natoli G, Costanzo A, lanni A, Templeton DJ, Woodgett JR, Balsano C and Levrero M (1997) Activation of SAPK/JNK by TNF receptor 1 through a noncytotoxic TRAF2-dependent pathway. Science 275: 200-203 
25. Goillot E, Raingeaud J, Ranger A, Tepper RI, Davis RJ, Harlow E and Sanchez I (1994) Mitogen-activated protein kinase-mediated Fas apoptotic signaling pathway. Proc. Natl. Acad. Sci. USA 94: 3302-3307

26. Yang X, Khosravi-Far R, Chang HY and Baltimore D (1997) Daxx, a novel Fasbinding protein that activates JNK and apoptosis. Cell 89: 1067-1076

27. Medema JP, Scaffidi C, Kischkel FC, Shevchenko A, Mann M, KrammerPH and Peter ME (1997) FLICE is activated by association with the CD95 death-inducing signaling complex (DISC). EMBO J. 16: 2794-2804

28. Wilhelm D, Bender K, Knebel A and Angel P (1997) The level of intracellular glutathione is a key regulator for the induction of stress-activated signal transduction pathways including JNK/SAPKs and p38 kinase by alkylating agents. Mol. Cell. Biol. 17: 4792-4800

29. Sanchez I, Hughes RT, Mayer BJ, Yee K, Woodgett, Avruch J, Kyriakis JM and Zon LI (1994) Role of SAPK/ERK kinase-1 in the stress-activated pathway regulating transcription factor c-Jun. Nature 372: 794-798

30. Xia Z, Dickens M, Raingeaud J, Davis RJ and Greenberg ME (1995) Opposing effects of ERK and JNK-p38 MAP kinases on apoptosis. Science 270: 13261331

31. Wajant H, Johannes FJ, HaasE, SiemienskiK, Schwenzer R, Schubert G, Weiss T, Grell M and Scheurich P (1998) Dominant-negative FADD inhibits TNFR60-, Fas/APO1-and TRAIL-R/Apo2-mediated cell death but not gene induction. Curr. Biol. 8: 113-116

32. Ichijo $H$, Nishida $E$, Irie $K$, ten Dijke $P$, Saitoh $M$, Moriguchi T, Tagaki M, Matsumoto K, Miyazono Kand Gotoh Y (1997) Induction of apoptosis by ASK1, a mammalian MAPKKK that activates SAPK/JNK and p38 signaling pathways. Science 275: $90-94$
33. Chang HY, Nishitoh H, Yang X, Ichijo H and Baltimore D (1998) Activation of apoptosis signal-regulating kinase 1 (ASK1) by the adapter protein Daxx. Science 18: 1860-1863

34. Nishina H, Fischer KD, Radvanyl L, Shahinian A, Hakem R, Rubie EA, Bernstein A, Mak TW, Woodgett JR and Penninger JM (1997) Stress-signalling protects thymocytes from apoptosis mediated by CD95 and CD3. Nature 385: 350-353

35. Park J, Kim I, Young JO, Lee K-W, Han P-L and Choi E-J (1997) Activation of CJun N-terminal kinase antagonizes an anti-apoptotic action of bcl-2. J. Biol. Chem. 272: $16725-16728$

36. Herr I, Wilhelm D, Bochler T, Angel P and Debatin K-M (1997) Activation of CD95 (APO-1/Fas) signaling by ceramide mediates cancer therapy-induced apoptosis. EMBO J. 16: 6200-6208

37. Herr I, Wilhelm D, Bochler T, Angel P and Debatin K-M (1998) JNK/SAPK activity is not sufficient for anticancer therapy-induced apoptosis involving CD95-L, TRAIL and TNF- $\alpha$. Int. J. Cancer, in press

38. Dhein J, Walczak H, Bumler C, Debatin K-M and Krammer PH (1995) Autocrine T-cell suicide mediated by APO-1 (Fas/CD95). Nature 373: 438-441

39. Chinnaiyan AM, Tepper CG, Seldin MF, O'Rourke K, Kischkel FC, Hellbardt S, Krammer PH, Peter ME and Dixit VM (1996) FADD/MORT1 is a common mediator of CD95 (Fas/APO-1) and tumor necrosis factor receptor-induced apoptosis. J. Biol. Chem. 271: 4961-4965 